\title{
Determining the Levels of Some Trace Elements and Heavy Metals (Cu, Mn, Mg, Fe, Zn, CO, Pb and CD) in the Cancers of Lip and Oral Cavity
}

Derya ÇAY DEMiR ( $\square$ imgesel_yasam@hotmail.com )

Yüzüncü Yıl Üniversitesi https://orcid.org/0000-0001-7271-9581

\section{Research Article}

Keywords: Lip and Oral Cavity Cancer, Blood, Serum, Trace Element, Heavy Metal

Posted Date: March 9th, 2021

DOI: https://doi.org/10.21203/rs.3.rs-309806/v1

License: (c) (i) This work is licensed under a Creative Commons Attribution 4.0 International License.

Read Full License 
DETERMINING THE LEVELS OF SOME TRACE ELEMENTS AND HEAVY METALS(Zn, Fe, Mn, $\mathrm{Mg}, \mathrm{Cu}, \mathrm{Cd}, \mathrm{Co}$ And Pb) IN THE CANCERS OF LIP AND ORAL CAVITY

\author{
Derya Çay Demir¹, Halit Demir ${ }^{1}$, Nazım Bozan $^{2}$, Şeyda Belli ${ }^{3}$ Canan Demir ${ }^{4}$ \\ 1-Division of Biochemistry, Department of Chemistry, Yuzuncu Yil University, Van, Turkey \\ 2-Department of Otorhinolaryngology, Faculty of Medicine, Yüzüncü Yll University, Van, Turkey. \\ 3-Department of Nose and Throat Diseases Clinic, Health Sciences University Bağcllar Education and \\ Research Hospital Ear, Istanbul, Turkey. \\ 4- Health Services Vocational High School, Yuzuncu Yil University, Van, Turkey.
}

\title{
ABSTRACT
}

Aim:

The aim of our study is to determine the relationship of certain trace elements and heavy metals with lip and oral cavity cancer.

\section{Materials And Methods:}

Blood counts of 21 individuals with lip and oral cavity cancer were compared with those in the control group consisting of 30 volunteer and healthy subjects. Levels of trace elements and heavy metals in the serum $(\mathrm{Cu}, \mathrm{Mn}, \mathrm{Mg}, \mathrm{Fe}, \mathrm{Zn}, \mathrm{Co}, \mathrm{Pb}, \mathrm{Cd})$ were determined using Atomic Absorption Spectrophotometer method at YUU Central Research Laboratory (Spectrometer: Thermo Scientific C103500100, China).

\section{Findings:}

In this study, the descriptive statistics and comparison results for $\mathrm{Cu}, \mathrm{Mn}, \mathrm{Mg}, \mathrm{Fe}, \mathrm{Zn}, \mathrm{Co}, \mathrm{Pb}, \mathrm{Cd}$ were found to be statistically significant ( $\mathrm{p}<0.05$ ). According to these results, $\mathrm{Zn}, \mathrm{Fe}, \mathrm{Mn}, \mathrm{Mg}$ and $\mathrm{Cu}$ levels which are necessary trace elements for human body were found to be significantly lower in patients than healthy control groups. $\mathrm{Cd}, \mathrm{Co}$ and $\mathrm{Pb}$ levels which are harmful and toxic to human body were found to be significantly higher in patients than healthy control groups $(\mathrm{p}<0.05)$.

\section{Results:}


Based on these findings of this first and new study in the literature, it was concluded that, trace elements and heavy metals $(\mathrm{Cu}, \mathrm{Mn}, \mathrm{Mg}, \mathrm{Fe}, \mathrm{Zn}, \mathrm{Co}, \mathrm{Pb}$ and $\mathrm{Cd})$ in the lip and oral cavity may affect the etiopathogenesis of the disease.

Keywords: Lip and Oral Cavity Cancer, Blood, Serum, Trace Element, Heavy Metal

\section{INTRODUCTION}

Cancer is simply defined as the uncontrolled proliferation of cells. The growth of cancer cells is unlimited. These cells secrete toxic and proteolytic enzymes by dissolving the healthy cells of tissues to make room for themselves and enlarge the area they cover [1]. One of the main factors that make cancer important is that it ranks first in the death ranking according to World Health Organization (2015) data [2].

Head and neck cancers constitute 5-8\% of all malignancies, and $25-35 \%$ of these cancers are the most common type of cancers after laryngeal cancers [3]. In the sixth order, in the oral cavity, squamous cell carcinoma in the oral cavity is the eighth in terms of death rankings[4].

Very few trace elements, which are sufficient for the body, [constitute less than $0.02 \%$ of the total body weight [5].The daily amount of trace elements required for the body is between $15-80 \mu \mathrm{g}$. The removal of trace elements under these amounts creates toxic effects, while overtake leads to various metabolic problems [6]. Despite these small proportions, trace elements have variety of important biological functions. Among these tasks are their functioning as antioxidants, cofactors for some enzymes, being a stabilizer for cell membranes, assisting for hormone activites, participation in anabolism activities, incorporation of metalloenzymes and metalloproteins into structural components, being protective against minerals that are toxic to metabolism, transportation of some substances in the circulatory system. Taking part in tasks, repairing wounds and damages, and accelerating learning. In addition to this, they are involved in the transmission of small electrical stimuli to the tissues of the heart, which enables the functioning of the heart muscle, the realization of brain functions, and the adjustment of the water pressure of the cells [6,7].

People are constantly exposed to a large number of toxic elements that are dispersed in nature. Lead, cadmium, cobalt, toxic trace elements, show toxic effects for people even at a low level $[5,8]$. Heavy metals are divided into two categories as vital and non-vital according to their degree of participation in biological activities. The vital heavy metals must be present in the organism at a certain level due to their inclusion in 
biological reactions; so they should be taken regularly with nutrients. Non-vital heavy metals can cause serious health problems even in very low concentrations. Whether a heavy metal is vital or not depends on the organism [9].

In this study, $\mathrm{Cu}, \mathrm{Mn}, \mathrm{Mg}, \mathrm{Fe}, \mathrm{Zn}, \mathrm{Co}, \mathrm{Pb}$ and $\mathrm{Cd}$ levels of lip and oral cavity cancer patients were examined. Trace and heavy metal levels determined in the blood serums of the patients were compared with healthy individuals. The aim of our study is to determine the relationship of certain trace elements and heavy metals with lip and oral cavity cancer.

\section{MATERIAL AND METHOD}

In this study, a total of 21 lip and oral cavity cancer patients, aged 18-65 years, diagnosed and followed in the Department of Otorhinolaryngology, Faculty of Medicine, Yüzüncü Yıl University and Otorhinolaryngology Clinic of Bağcılar Training and Research Hospital of the University of Health Sciences were studied by taking blood samples between June 2017 and January 2018. Before the blood samples were collected, the approval of the Local Ethics Committee of Clinical and Laboratory Researches of Van Training and Research Regional Hospital were taken in this study. In addition, in order to compare the blood results obtained from individuals with lip and oral cavity cancer, 30 volunteers and healthy individuals between the ages of 18-65 were used as a control group.

In this study, 4cc blood biochemistry tube was taken from the individuals, who had lip and oral cavity cancer and healthy control groups. The blood samples were centrifuged for 5 minutes at $4000 \mathrm{rpm}$ in Nüve NF 800 brand centrifuge instrument. Serums were kept at $-20^{\circ} \mathrm{C}$ until the day they were treated. Once the target number was reached, all samples were carefully brought to room temperature $\left(15-18{ }^{\circ} \mathrm{C}\right)$ before mixing. The levels of trace elements and heavy metals $(\mathrm{Cu}, \mathrm{Mn}, \mathrm{Mg}, \mathrm{Fe}, \mathrm{Zn}, \mathrm{Co}, \mathrm{Pb}$ and $\mathrm{Cd})$ in serum were determined by Atomic Absorption Spectrophotometer method in the Yuzuncu Y1l Universty Center Research Laboratory (Spectrometer: Thermo Scientific C103500100, China).

\subsection{Statistical Analysis}

Descriptive statistics for the features under consideration were expressed as Mean and Standard Deviation. T-Test was used in the cases where normal distribution condition was provided in paired group comparisons, and Mann-Whitney U test statistic was used in cases where normal distribution condition was not 
provided. The statistical significance level was measured as 0.05 and the SPSS statistical package program was used for the measurements.

\section{FINDINGS}

Table I. Patient and healthy control group trace element levels.

Descriptive statistics and comparison results for $\mathrm{Cu}, \mathrm{Mn}, \mathrm{Mg}, \mathrm{Fe}, \mathrm{Zn}, \mathrm{Co}, \mathrm{Pb}, \mathrm{Cd}$ are given in Table I. When Table I was observed, the difference between the mean levels of the patient and control groups was found to be statistically significant $(\mathrm{p}<0.05)$.

A trace element $(\mathrm{Cu})$ level is shown in Table I. The concentration of $\mathrm{Cu}$ element was found to be 2.3498 \pm 0.3342 in healthy control group and $0.7138 \pm 0.1765$ in lip and oral cavity cancer patients. The statistical significance between the two groups was found as $\mathrm{p}<0.05$.

The level of Mn from trace elements is shown in Table I. The concentration level of Mn was $0.1282 \pm$ 0.0096 in the healthy control group and $0.0338 \pm 0.0119$ in the patients with lip and oral cavity cancer. The statistical significance between the two groups was $\mathrm{p}<0.05$.

The Mg level of trace elements is shown in Table I. The concentration level of $\mathrm{Mg}$ element was 39.8100 \pm 1.6171 in healthy control group and $25.2958 \pm 1.2402$ in patients with lip and oral cavity cancer. The statistical significance between the two groups was $\mathrm{p}<0.05$.

The level of Fe, which is also a trace element, is shown in Table I. The concentration level of Fe was $4.8962 \pm 0.1835$ in the healthy control group and $1.2473 \pm 0.5809$ in the patients with lip and oral cavity cancer. The statistical significance between the two groups was $\mathrm{p}<0.05$.

A trace element and a very strong antioxidant element $\mathrm{Zn}$ are shown in Table I. The concentration level of $\mathrm{Zn}$ was $2.5628 \pm 0.2408$ in the healthy control group and $0.7828 \pm 0.2938$ in the patients with lip and oral cavity cancer. The statistical significance between the two groups was $\mathrm{p}<0.05$.

The level of Co, which is a heavy metal, is shown in Table I. The concentration of Co element was $0.0174 \pm 0.0043$ in healthy control group and $0.0759 \pm 0.0244$ in patients with lip and oral cavity cancer. The statistical significance between the two groups was $\mathrm{p}<0.05$.

The level of $\mathrm{Pb}$ from heavy metals having toxic effects which are dangerous for human health is shown in Table I. The concentration level of $\mathrm{Pb}$ was $0.0641 \pm 0.0139$ in healthy control group and $0.2227 \pm 0.0955$ in lip and oral cavity cancer patients. The statistical significance between the two groups was $\mathrm{p}<0.05$. 
A heavy metal Cd level is shown in Table I. The concentration level of Cd was $0.0488 \pm 0.0167$ in healthy control group and $0.3132 \pm 0.1619$ in patients with lip and oral cavity cancer. The statistical significance between the two groups was $\mathrm{p}<0.05$.

\section{CONCLUSION \& DISCUSSION}

The aim of this study was to measure some levels of trace and heavy metals in patients with cancer of the lips and oral cavity and to correlate with the degree of the disease.

Lip and oral cavity cancers are biochemically important and there are limited number of clinical and laboratory studies to explain the pathophysiology of these cancers and to present new information in the treatment. Therefore, we aimed to contribute to the literatüre by explaining the biochemical pathogenesis of lip and oral cavity cancer by examining some trace element and heavy metal $(\mathrm{Zn}, \mathrm{Fe}, \mathrm{Mn}, \mathrm{Mg}, \mathrm{Cu}, \mathrm{Cd}, \mathrm{Co}$ and $\mathrm{Pb}$ ) levels in serum blood samples taken from patients who were admitted to the ENT service with a diagnosis of lip and oral cavity cancer.

In a study on laryngeal cancer, high levels of nickel, arsenic and copper have been reported in patients' sera before treatment [10]. In a study on bladder cancer patients, it was reported that serum $\mathrm{Cu}, \mathrm{Pb}$ and $\mathrm{Fe}$ levels were significantly higher than healthy control groups [11]. In another study on colon cancer patients, $\mathrm{Cu}$ level was found to be significantly higher than healthy control group [12]. In another study, it was reported that $\mathrm{Cu}$ level in the blood of lung cancer patients was lower than the healthy control group [13]. In the study conducted by Bilici et al. Related with ovarian cancer, it was reported that $\mathrm{Cu}$ levels in the preoperative blood of the patients were higher compared to the control group after the operation, but not statistically significant [14]. In another study on preterm birth and premature infants, no significant difference was found in terms of $\mathrm{Cu}$ levels between postpartum mother blood serum and umbilical cord blood sera and placenta tissue samples and healthy pregnancies [15]. In a study conducted on Peyronie patients, it was found that the Cu levels in the blood serum of the patients were significantly lower than the healthy control groups [16]. In another study on patients with burst fractures, the $\mathrm{Cu}$ levels in blood serum of the patients were significantly lower than healthy control groups [17]. In a study on breast cancer, it was reported that the $\mathrm{Cu}$ and $\mathrm{Mg}$ levels in the blood of patients before and after radiotherapy were significantly different compared to the healthy control group [18]. In two different studies on breast cancer, it was reported that the $\mathrm{Cu}$ levels in the patients' blood were higher than the healthy control groups [19]. In this study on lip and oral cavity cancers, the difference between the mean levels of $\mathrm{Cu}$ 
and control group was statistically significant ( $\mathrm{p}<0.05$ ). In our study, it was found that the Cu level in the blood of patients with lip and oral cavity cancer was significantly lower than the healthy control group (Table I). The concentration of $\mathrm{Cu}$ element was $2.3498 \pm 0.3342$ in healthy control group and $0.7138 \pm 0.1765$ in lip and oral cavity cancer patients. The statistical significance between the two groups was found to be $\mathrm{p}<0.05$ (Table I). Low levels of $\mathrm{Cu}$ in the patient group can affect the prognosis of the disease, which plays a role in many important biochemical processes in metabolism. In addition, low $\mathrm{Cu}$ levels may be determinative in the etiopathogenesis of the lips and oral cavity cancers.

$\mathrm{Mn}$ and $\mathrm{Zn}$ levels were found to be lower in patients with bladder cancer than in healthy controls [11]. In a study on colon cancer patients, Mn level was found to be higher than that of healthy control group [12]. In another study, it was found that patients with lung cancer had higher levels of Mn than healthy controls [13]. In another study on prostate cancer patients, Mn level was found to be significantly higher than healthy control group [20]. In a study on patients with ovarian cancer, Mn level was found to be lower in the preoperative group compared to the control group and the postoperative group [14]. In a study on Peyronie patients, it was determined that $\mathrm{Mn}, \mathrm{Cu}, \mathrm{Zn}$ and $\mathrm{Fe}$ levels in the blood serum of the patients were statistically significantly lower than the healthy control groups [16]. In a study on patients with burst fractures, Mn levels in blood sera of the patients were significantly lower than healthy control groups [17]. In this study on lip and oral cavity cancers, the difference between Mn levels and patient and control group mean was statistically significant $(\mathrm{p}<0.05)$. In our study, it was found that Mn levels in the blood of patients with lip and oral cavity cancer were significantly lower than the healthy control group (Table I). The concentration of Mn was $0.1282 \pm 0.0096$ in the healthy control group and $0.0338 \pm 0.0119$ in the patients with lip and oral cavity cancer $(\mathrm{p}<0.05)$. The low level of Mn, which is an important element in the patient group, may affect the progroze of the disease and this indicates that the cells do not have enough Mn substance. Low levels of Mn in the study of the superoxide dismutase enzyme system, which protects the cells from the carcinogenic effects of chemicals and radiation, may affect the etiopathogenesis of the disease in lip and oral cavity cancers.

In a study on patients with colon cancer, it was found that $\mathrm{Mg}$ level was higher than that of healthy people [12]. In a study on lung cancer, it was reported that $\mathrm{Mg}$ level was significantly lower than healthy control group [13]. In a study conducted on patients with ovarian cancer, it was reported that Mg levels were higher in the preoperative group, control group and postoperative group [14]. In a study on preterm and premature infants, maternal serum $\mathrm{Mg}$ level was found to be lower than healthy control group, whereas placental magnesium was found to be higher in the group presenting with PPROM but there was no statistically significant difference 
between umbilical cord magnesium levels and those in the healthy group [15]. In a study on patients with burst fractures, serum Mg levels were significantly lower than healthy control groups [17]. In this study on lip and oral cavity cancers, the difference between the patient and control group mean in terms of $\mathrm{Mg}$ levels was found to be statistically significant ( $\mathrm{p}<0.05$ ). In our study, it was found that the level of $\mathrm{Mg}$ in the blood of patients with lip and oral cavity cancer was significantly lower than in the healthy control group (Table I). The concentration level of $\mathrm{Mg}$ element was $39.8100 \pm 1.6171$ in healthy control group and $25.2958 \pm 1.2402$ in patients with lip and oral cavity cancer. The low level of $\mathrm{Mg}$ in the patient group, which has a role in many important biochemical events in metabolism, may affect the prognosis of the disease. In lip and oral cavity cancers, low $\mathrm{Mg}$ levels may be determinant in the etiopathogenesis of the disease.

In a study on breast cancer patients, $\mathrm{Zn}, \mathrm{Cu}, \mathrm{Se}$ and $\mathrm{Fe}$ concentrations were found to be high [19]. In addition, Fe levels in breast cancer cases were found to be higher than control groups [19]. In a study on bladder cancer patients, Fe levels were significantly different compared to the healthy control group [11]. In another study, iron levels were higher in lung cancer, hepatocellular carcinoma and colorectal cancer patients compared to healthy control group [21]. In a literature study, it was reported that the excess iron load directly increases the formation of free hydroxy radicals from hydroxyl peroxide and superoxide (by Fenton and Haber arttır Weiss reactions), thus increasing the risk of cancer formation [22]. In another study, serum iron levels in invasive bladder cancers were reported to be lower than normal and non-invasive types [23]. In a study on prostate cancer, Fe levels were significantly higher than healthy controls [20]. In a study on patients with ovarian cancer, Fe levels of the preoperative group were reported to be low compared to the control group and post-operative group [14]. In a study on Peyronie patients, it was found that the levels of Fe in patients with blood serum were significantly lower than those of healthy control groups [16]. In a study on patients with burst fractures, the levels of $\mathrm{Fe}$ in patients with blood serum were significantly higher than healthy control groups [17]. In this study on lip and oral cavity cancers, the difference in iron levels between the patient and control group means was statistically significant ( $\mathrm{p}<0.05$ ). In our study, it was found that the level of Fe in the blood of patients with lip and oral cavity cancer was significantly lower than the healthy control group (Table I). The concentration level of Fe element was $4.8962 \pm 0.1835$ in the healthy control group and $1.2473 \pm 0.5809$ in the patients with lip and oral cavity cancer $(\mathrm{p}<0.05)$. The low level of iron in the patient group, which has a vital role in general cellular functioning and is primarily involved in energy metabolism in the organism, may affect the prognosis of the disease. This may cause problems in the energy metabolism of the cells, and may lead to disruptions in many 
biological activities such as oxygen, electrons and many enzymes, and DNA synthesis. Furthermore, in patients with lip and oral cavity cancers, low Fe levels may affect the etiopathogenesis of the disease.

Low Zn levels were found in patients with ovarian and cervical cancer [24,25]. In a study on colon cancer, $\mathrm{Zn}$ level was found to be higher than that of healthy individuals [12]. In another study, it was observed that $\mathrm{Zn}$ levels in blood serum of bladder cancer patients were lower than healthy control group [11]. In a different study, it was observed that Zn levels were lower in the blood serum of lung cancer patients compared to the healthy control group [13]. In a study on prostate cancer patients, zinc level was found to be lower than that of healthy control group [20]. In a study on preterm and premature infants, both the maternal and umbilical cord serum $\mathrm{Zn}$ levels were found to be lower in the group presenting with PPROM, whereas there was no statistically significant difference between the groups in terms of placental tissue Zn levels [15]. In a study conducted on Peyronie patients, it was determined that $\mathrm{Mn}, \mathrm{Cu}, \mathrm{Zn}$ and $\mathrm{Fe}$ levels in the blood serum of the patients were significantly lower than the healthy control groups [16]. In a study on patients with burst fractures, $\mathrm{Zn}$ levels in the blood serum of the patients were significantly lower than healthy control groups [17]. In this study on lip and oral cavity cancers, the difference between $\mathrm{Zn}$ levels and the mean of control group was statistically significant $(\mathrm{p}<0.05)$. In our study, the level of zinc in the blood of patients with lip and oral cavity cancer was found to be significantly lower than in the healthy control group (Table I). Zn element concentration level was $2.5628 \pm$ 0.2408 in healthy control group and $0.7828 \pm 0.2938$ in lip and oral cavity cancer patients $(\mathrm{p}<0.05)$. A very strong antioxidant element, Zn level, may affect the progroze of the disease in the patient group. Furthermore, in patients with lip and oral cavity cancers, low Zn levels may affect the etiopathogenesis of the disease.

In a literature study, it was reported that osteoblast-like cells can be transformed into carcinogenic phenotype in individuals exposed to Co, and they also activate the expression of genes associated with cancer [19]. Schnorr et al. (1995) reported that cobalt was associated with lung cancer [27]. In another study on lung cancer, it was reported that Co levels in blood sera of the patients were significantly higher than the healthy control group [13]. In studies conducted on animals in order to investigate the effects of cobalt, cobalt has been reported to cause myocytosis as a result of accumulation in myocardium, prevent sperm production in mice and have negative effects on reproduction [26]. As reported by Ozmen et al., [28] high levels of Ni and Co concentrations were detected in blood sera in patients with prostate cancer. In a study on patients with bladder cancer, it was reported that the Co levels in the blood sera of the patient individuals were significantly higher than the healthy control groups [11]. In a study on patients with ovarian cancer, the Co level in the preoperative group was found to be lower compared to the control group and the postoperative group, but it was not 
statistically significant [14]. In a study on Peyronie patients, it was found that there was no significant difference between the levels of $\mathrm{Co}$ and $\mathrm{Cd}$ in the blood serum of the patients and the healthy control groups [16]. In a study on patients with burst fractures, the level of Co in patients with blood serum was significantly lower than healthy control groups [17]. In this study on lip and oral cavity cancers, the difference between cobalt levels and the mean levels of the control group was statistically significant $(\mathrm{p}<0.05)$. In our study, it was found that Co level in blood of patients with lip and oral cavity cancer was significantly higher than healthy control group (Table I). The concentration of Co element was $0.0174 \pm 0.0043$ in healthy control group and $0.0759 \pm 0.0244$ in patients with lip and oral cavity cancer. The statistical significance between the two groups was found to be $p$ $<0.05$ (Table I). The high level of Co in a patient group may affect the prognosis of the disease. Moreover, in patients with lip and oral cavity cancers, high Co levels may affect the etiopathogenesis of the disease. High Co levels in lip and oral cavity can increase the level of oxidative stress in cells, which may accelerate the development of cancer.

In a study by Çobanoğlu et al., it was reported that the level of $\mathrm{Pb}$ in the blood serum of lung cancer patients was significantly higher than the healthy control group [13]. In a study on kidney cancer, it was determined that $\mathrm{Pb}$ levels in the blood serum of the patients were higher than the healthy control group [29]. In a literature study, it was reported that $\mathrm{Pb}$ level in renal cell carcinoma cells was significantly higher than healthy individuals [30]. In another study, it was determined that $\mathrm{Pb}$ levels in blood sera of colon cancer patients were higher than healthy control group [12]. In a study on patients with ovarian cancer, $\mathrm{Pb}$ levels in the preoperative group were found to be higher compared to the control group and lower than in the postoperative group and it was reported to be statistically significant [14]. In a study on Burst fracture patients, Pb level in the blood serum of the patients was found to be significantly higher than healthy control groups [17]. In this study on lip and oral cavity cancers, the difference between lead and mean levels of the control groups was statistically significant ( $p$ $<0.05)$. In our study, it was found that the level of $\mathrm{Pb}$ in the blood of patients with lip and oral cavity cancer was significantly higher than the healthy control group (Table I). The concentration level of $\mathrm{Pb}$ was $0.0641 \pm 0.0139$ in healthy control group and $0.2227 \pm 0.0955$ in lip and oral cavity cancer patients. The statistical significance between the two groups was $\mathrm{p}<0.05$ (Table I). A high level of $\mathrm{Pb}$ in the patient group, which has a dangerous toxic effect on human health, may affect the progroze of the disease. Although this is an indication of excessive $\mathrm{Pb}$ entry into cells, high $\mathrm{Pb}$ levels in the lips and oral cavity can affect the etiopathogenesis of the disease. Again, high $\mathrm{Pb}$ level in lip and oral cavity can accelerate the development of cancer by increasing the level of oxidative stress in cells. 
In a study on lung cancer, it was found that the levels of $\mathrm{Cd}$ in the blood serum of the patients were higher than the healthy control groups [13]. In a study on bladder cancer patients, it was found that the levels of $\mathrm{Cd}, \mathrm{Ni}$ and $\mathrm{Co}$ in the blood serum of the patients were higher than the healthy control groups [11]. In another study, kidney cancer was studied and the levels of $\mathrm{Cd}$ in the blood serum of the patients were found to be higher than the healthy control groups [29]. In a study conducted on patients with colon cancer, it was determined that the Cd level in the blood of the patients was higher than the healthy people [12]. In a study by Pirinççi et al., it was determined that $\mathrm{Cd}$ level in renal cell carcinoma cells increased significantly compared to healthy individuals [30]. In a study conducted in patients with glioma cancer, it was reported that the Cd level in the serum of the patients was significantly higher than the healthy individuals [31]. In another study conducted on patients with ovarian cancer, the $\mathrm{Cd}$ level in the preoperative group was reported to be significantly higher than the control group and the postoperative group [14]. In a study on Peyronie patients, it was found that there was no significant difference between the levels of $\mathrm{Co}$ and $\mathrm{Cd}$ in the sera of the patients and the healthy control groups [16]. In a study on patients with burst fractures, the Cd level in the blood serum of the patients was found to be significantly lower than the healthy control groups [17]. In this study on lip and oral cavity cancers, the difference between $\mathrm{Cd}$ and mean control groups was statistically significant ( $\mathrm{p}<0.05)$. In our study, the level of $\mathrm{Cd}$ in the blood of patients with lip and oral cavity cancer was found to be significantly higher than in the healthy control group (Table I). The concentration level of Cd was $0.0488 \pm 0.0167$ in healthy control group and 0.3132 \pm 0.1619 in patients with lip and oral cavity cancer. The statistical significance between the two groups was found to be $\mathrm{p}<0.05$ (Table I). A significant level of heavy metal Cd level in the patient group may affect the progroze of the disease. This may indicate an excess of $\mathrm{Cd}$ entering the cells. Furthermore, in patients with lip and oral cavity cancers, high Cd level may play a role in the etiopathogenesis of the disease. Again, high Cd level in lip and oral cavity can accelerate cancer development by increasing the level of oxidative stress in cells.

In conclusion, in this study, descriptive statistics and comparison results for $\mathrm{Cu}, \mathrm{Mn}, \mathrm{Mg}, \mathrm{Fe}, \mathrm{Zn}, \mathrm{Co}$, $\mathrm{Pb}, \mathrm{Cd}$ were statistically significant $(\mathrm{p}<0.05)$. According to these results, $\mathrm{Cu}, \mathrm{Mn}, \mathrm{Mg}, \mathrm{Fe}$ and $\mathrm{Zn}$ levels, which are necessary trace elements for human body, were found to be significantly lower in patients than healthy control groups. $\mathrm{Co}, \mathrm{Pb}$ and $\mathrm{Cd}$ levels which are harmful and toxic for human body were found to be significantly higher in patients than healthy control groups. According to these results, trace elements and heavy metal levels $(\mathrm{Cu}, \mathrm{Mn}, \mathrm{Mg}, \mathrm{Fe}, \mathrm{Zn}, \mathrm{Co}, \mathrm{Pb}, \mathrm{Cd})$ in lip and oral cavity can affect the etiopathogenesis of the disease. Because of the small number of patients in our study and the hospital where we conducted the study serves patients in a local area, we believe that it would be useful to conduct a study in a larger area and on a larger number of 
patients. This study is the first and new study in the literature. We believe that this study will shed light on the studies on lip and oral cavity cancers.

Acknowledgement: We thank to the patients and healty volunteers who participated in the study.

Conflict of Interest: The authors declare no potential conflicts of interest with respect to the research, authorship, and/or publication of this article.

Author's Contributions: Research concept and design; data collecting, analysis and interpretation of data. All authors participating in this study have equal contributions to the article. All authors approved the final version of the manuscript.

This study was supported by VAN YYU BAPB (Scientific Research Projects Department) as Project No: FYL2017-6088. We would like to thank VAN YYU BAPB (Scientific Research Projects Department) for their contributions

\section{REFERENCES}

1. Dalgıç G, Karadağ A, Kuzu N. Nursing Care for The Developing Stomatitis Due to Chemotherapy. Cerrahpaşa Univ. Journal of The School of Nursing, 1998; 2: 53-59, (in Turkish)

2. Yilmaz B. Cancer Overview Cancer Screening Programs Overview of Alternative Treatments. http://istanbulsaglik.gov.tr/w/sb/per/belge/kansere_genel.pdf Haydarpaşa Numune Education and Research Hospital Medical Oncology Unit, İstanbul, 2011, Accessed 17 June 2017

3. Şen E. Department of Otolaryngology Sentinel Lymph Node Biopsy in Oral Cavity Cancers (dissertation) T.C Uludağ Univ Faculty of Medicine, Bursa, 2008 (in Turkish)

4. Basıry MN. Determination of Awareness Levels of Oral Cancer and Risk Factors Among Turkish Armed Forces Personnel (dissertation). General Staff Gulhane Military Medical Academy Health Sciences, Ankara, 2015 (in Turkish)

5. Gezh SAS. Investigation of Some Trace Element ( $\mathrm{Zn}, \mathrm{Fe}, \mathrm{Mn}, \mathrm{Mg}, \mathrm{Cu}, \mathrm{Cd}, \mathrm{Co} \mathrm{Ve} \mathrm{Pb}$ ) Levels in Patients with Burst Fracture (dissertation), Division of Biochemistry, Department of Chemistry, Van Yuzuncu Yil University, Van, 2016, (in Turkish)

6. Emre Ö. Detection of Some Trace Elements, Minerals And Heavy Metals (Cr, Al, $\mathrm{Se}, \mathrm{Pb}, \mathrm{Cd}, \mathrm{Mn}, \mathrm{Cu}, \mathrm{Mg}$, Zn, Co Ve Ca) Before And After Chemotherapy In Patients With Colon Cancer (dissertation), Division of Biochemistry, Department of Chemistry, Van Yuzuncu Yil University, Van, 2011, (in Turkish) 
7. Çavuşoğlu K, Çakır Arıca Ş, Kurtman Ç. Determining The Change In Plasma Trace Element Levels Of Lung Cancer Patients Undergoing Radiotherapy. J Firat Univ Health Sciences 2008; 22 (4): 211 - 222 (in Turkish)

8. Morais S, Costa FG, Pereira ML. Heavy Metals and Human Health. Environmental Health- Emerging Issues and Practice 2010; 10: 227-247

9. Alacabey İ. Isotherm and Thermodynamic Analysis of Adsorption of Natural and Activated Lake Van Sediment Samples (Bottom Mud) with Some Heavy Metals (dissertation), Division of Biochemistry, Department of Chemistry, Van Yuzuncu Yil University, Van, 2014, (in Turkish)

10. Rostkowska, Nadolska B, Pospiech L, Bochnia M. Content of trace elements in the serum of patients with carcinoma of the larynx. Arch. Immunol. Ther. Exp. 1999; 46: 321-325

11. Yildız I. Serum Trace Element Levels in Bladder Cancer Patients, (dissertation), Division of Biochemistry, Department of Chemistry, Van Yuzuncu Yil University, Van, 2015, (in Turkish)

12. Emre Ö, Demir H, Dogan E, Esen R, Gur T, Gonullu E, Turan N, Ozbay M.F. Plasma Concentrations of Some Trace Element and Heavy Metals in Patients with Metastatic Colon Cancer. Journal of Cancer Therapy, $2013 ; 4: 1085-1090$

13. Çobanoğlu U, Demir H, Sayır F, Duran M, Mergan D. Some Mineral, Trace Element and Heavy Metal Concentrations in Lung Cancer. Asian Pacific Journal of Cancer Prevention, 2010; 11, 1383-1388,

14. Bilici M. Examination Of Trace Element Levels ( $\mathrm{Zn}, \mathrm{Cu}, \mathrm{Mg}, \mathrm{Pb}, \mathrm{Mn}, \mathrm{Cd}$, Co Ve Fe) In The Blood Before And After Surgery In Ovarian Cancer Patients (dissertation). Division of Biochemistry, Department of Chemistry, Van Yuzuncu Yil University, Van, 2014, (in Turkish)

15. Küçükaydın Z, Kurdoğlu M, Kurdoğlu Z, Demir H, Yörük İH. Selected maternal, fetal and placental trace element and heavy metal and maternal vitamin levels in preterm deliveries with or without preterm premature rupture of membranes. The Journal of Obstetrics and Gynaecology Research 2018; 44(5): 880-889

16. Güneş M, Asla, R, Eryılmaz R, Demir H, Take K. Levels of serum trace elements in patients with Peyronie. The Aging Male 2018; 17: 1-4,

17. Gezh SAS, Aycan A, Demir H, Bozlına C. Determination of trace element in patients with burst fractures. Turkish Journal of Trauma and Emergency Syrgery 2018; 24(3): 244-248

18. Seven G. Examination of trace elements and heavy metal levels ( $\mathrm{Zn}, \mathrm{Cu}, \mathrm{Pb}, \mathrm{Cd}, \mathrm{Mn}, \mathrm{Mg}$ ve $\mathrm{Co})$ and some biochemical (catalase and carbonic anhydrase) parameters before and after radiotherapy in patients with head and neck and stomach cancer (dissertation), Division of Biochemistry, Department of Chemistry, Van Yuzuncu Yil University, Van, 2010, (in Turkish) 
19. Demir H, Demir C. Effect of heavy metal and some trace element levels on radiotherapy taken breast cancer patients. Medical Science and Discovery 2016; 3(3):116-119

20. Kaba M, Pirinççi N, Yuksel MB, Gecit I, Gunes M, Ozvere H, Eren H, Demir H. Serum levels of trace elements in patients with prostate cancer. Asian Pac J Cancer Prev 2014; 15(6):2625- 2629

21. Tsunehiro O, Toshihiro K, Koji M. A case-case study comparing the usefulness of serum trace elements $(\mathrm{Cu}$, $\mathrm{Zn}$ and Se) and tumor markers (CEA, SCC and SLX) in non-small cell lung cancer patients. Anticancer Res $2003 ; 23,605-61$

22. Dayani PN, Bishop MC, Black K, Zeltzer PM. Desferoxamine (DFO)-mediated iron chelation: rationale for a novel approach to therapy for brain cancer. J Neurooncol 2004; 67, 367- 377

23. Ilker A, Akçay T, Çakatay U. Relation between bladder cancer and protein oxidation. Int Urol Nephrol 2003; $35,345-50$

24. Cunzhi H, Jiexian J, Xianwen Z. Serum and tissue levels of six trace elements and copper/ zinc ratio in patients with cervical cancer and uterine myoma. Biol Trace Elem Res 2003; 94: 113- 122

25. Yaman M, Kaya G, Simsek M. Comparision of trace elements concentrations in cancerous and noncancerous human endometrial and ovary tissues. Int JGynecol Cancer 2007; 17: 220-228

26. Anderson MB, Pedigo NG, Katz, RP, George WJ. Histopathology of testes from mice chronically treated with cobalt. Reproductive toxicology 1992; 6, 41-50

27. Schnorr TM, Steenland K, Thun MJ, Rinsky RA. Mortality in a cohort of antimony smelter workers. Am J Ind Med 1995; 27, 759-770

28. Ozmen H, Erulas AF, Karatas F, Cukurovali A, Yalcin O. Comparison of the concentration of trace metals $(\mathrm{Ni}, \mathrm{Zn}, \mathrm{Co}, \mathrm{Cu}$ and $\mathrm{Se}), \mathrm{Fe}$, vitamins $\mathrm{A}, \mathrm{C}$ and $\mathrm{E}$, and lipid peroxidation in patients with prostate. Clin Chem Lab Med 2006; 44, 175-9

29. Gecit I, Kavak S, Demir H, Güneş M, Pirinçci N, Cetin C, Ceylan K, Benli E, Yildiz I. Serum Trace Element Levels in Patients with Bladder Cancer. Asian Pacific Journal Cancer Prevention 2011; 12(12):3409-13

30. Pirinççi N, Gecit I, Gunes M, Kaba M, Tanik S, Yuksel MB, Arslan H, Demir H. Levels of serum trace elements in renal cell carcinoma cases. A. Pac J Cancer Prev 2013; 14:499-502

31. Arslan M, Demir H, Arslan H, Gokalp AS, Demir C. Trace elements, heavy metals and other biochemical parameters in malignant glioma patient. Asian Pac J Cancer Prev 2011; 12(2):447- 51 
Table I. Patient and healthy control group trace element levels.

\begin{tabular}{|c|c|c|c|c|c|c|c|c|c|}
\hline & \multirow{2}{*}{\multicolumn{4}{|c|}{ Healthy control group $n=30$}} & \multicolumn{5}{|c|}{ Lip and oral cavity cancer patients group $n=$} \\
\hline & & & & & 21 & & & & $\mathrm{P}$ \\
\hline & Mean & SEM. & Min. & Max. & Mean & SEM. & Min. & Max. & \\
\hline $\mathrm{Cu} \mathrm{mg/L}$ & 2.3498 & 0.3342 & 2.026 & 2.916 & 0.7138 & 0.1765 & 0.41 & 1.017 & 0.001 \\
\hline $\mathrm{Mn} \mathrm{mg} / \mathrm{L}$ & 0.1282 & 0.0096 & 0.114 & 0.141 & 0.0338 & 0.0119 & 0.016 & 0.049 & 0.001 \\
\hline $\mathrm{Mg} \mathrm{mg/L}$ & 39.8100 & 1.6171 & 37.134 & 40.088 & 25.2958 & 1.2402 & 21.8315 & 27.0575 & 0.001 \\
\hline $\mathrm{Fe} \mathrm{mg} / \mathrm{L}$ & 4.8962 & 0.1835 & 4.572 & 5.103 & 1.2473 & 0.5809 & 0.3265 & 2.3105 & 0.001 \\
\hline $\mathrm{Zn} \mathrm{mg/L}$ & 2.5628 & 0.2408 & 2.248 & 2.965 & 0.7828 & 0.2938 & 0.32 & 1.4245 & 0.001 \\
\hline Co mg/L & 0.0174 & 0.0043 & 0.011 & 0.023 & 0.0759 & 0.0244 & 0.0385 & 0.12 & 0.001 \\
\hline $\mathrm{Pb} \mathrm{mg} / \mathrm{L}$ & 0.0641 & 0.0139 & 0.046 & 0.085 & 0.2227 & 0.0955 & 0.125 & 0.395 & 0.001 \\
\hline $\mathrm{Cd} \mathrm{mg/L}$ & 0.0488 & 0.0167 & 0.021 & 0.081 & 0.3132 & 0.1619 & 0.101 & 0.823 & 0.001 \\
\hline
\end{tabular}

